\title{
PERKEMBANGAN AKTIVITAS ENZIM PENCERNAAN LARVA RAJUNGAN Portunus pelagicus
}

\section{DEVELOPMENT OF ENZYME DIGESTIVE ACTIVITY OF BLUE CRAB Portunus pelagicus LARVAE}

\author{
Andi Nikhlani* dan Komsanah Sukarti \\ Staf Pengajar Jurusan Budidaya Perairan FPIK UNMUL, Samarinda \\ *E-mail: andini.makmur@yahoo.com
}

\begin{abstract}
Seed production continuity of Portunus pelagicus larvae had been conducted but the results were still un-consistent. Digestive activity was known to be associated with the type of feed consumed by larvae. Amylase, lipase, and trypsin enzymes were used as a biological indicators to measure the digestion of feed. The aim of this study was to describe the activity of digestive enzymes in blue swimming crab larvae. Digestive enzyme activity data obtained was presented in graphical form and analyzed descriptively. Based on the results of the study, the enzyme activity of amylase, lipase and trypsin was detected at the $1^{\text {st }}$ day. The pattern of amylase enzyme activity showed an increased from the larvae of 1 st day until the $17^{\text {th }}$ day then decreased until the end of the study. The activity of trypsin enzyme was high on $1^{\text {st }} d a y$, but decreased on the $3^{\text {rd }}$ and $5^{\text {th }}$ days, and increased again on the $7^{\text {th }}$ day until the last day of the study. The highest activity of amylase and trypsin during this time period occurred in the $11^{\text {th }}$ day. Lipase enzyme activity tended to be stable from the beginning to the end of the study. In cultivation applications, artificial feeding with carbohydrate, protein and high fat content should be performed when the larvae are $11^{\text {th }}$ days.
\end{abstract}

Keywords: digestive, amylase, lypase, trypsin, blue swimming crab larva

\begin{abstract}
ABSTRAK
Keberlanjutan produksi larva rajungan Portunus pelagicus telah dilakukan, namun sintasan yang diperoleh belum stabil. Aktivitas pencernaan diketahui sangat terkait dengan jenis pakan yang dikonsumsi larva sehingga berdampak terhadap pertumbuhan dan sintasannya. Enzim amilase, lipase, pepsin dan tripsin merupakan indikator biologis yang dapat menunjukkan kesesuaian jenis pakan yang dikonsumsi larva melalui kemampuannya untuk mencerna. Tujuan penelitian ini adalah untuk mengetahui aktivitas enzim pencernaan pada larva rajungan. Data aktivitas enzim pencernaan yang diperoleh disajikan dalam bentuk grafik dan dianalisa secara deskriptif. Berdasarkan hasil penelitian, aktivitas enzim amilase, lipase dan tripsin mulai terdeteksi pada larva umur satu hari. Pola aktifitas enzim amilase menunjukkan peningkatan sejak larva berumur satu hari hingga hari ketujuhbelas kemudian cenderung menurun sampai akhir penelitian. Aktivitas enzim tripsin tinggi pada hari kesatu, tapi cenderung menurun pada hari ketiga dan kelima, dan meningkat lagi pada hari ketujuh sampai hari terakhir penelitian. Aktivitas amilase dan tripsin tertinggi selama periode waktu tersebut terjadi pada larva umur sebelas hari, sedangkan aktivitas enzim lipase cenderung stabil dari awal sampai akhir penelitian. Aplikasi budidaya, pemberian pakan buatan dengan kandungan karbohidrat, protein dan lemak tinggi sebaiknya dilakukan saat larva berumur sebelas hari.
\end{abstract}

Kata kunci: pencernaan, enzim, amilase, lipase, tripsin, larva rajungan

\section{PENDAHULUAN}

Upaya produksi benih secara terkontrol telah dilakukan melalui beberapa penelitian yang mengarah pada peningkatan sintasan guna mendukung kontinuitas pasokan benih. Namun kegagalan produksi benih masih sering dialami terutama pada stadia awal, sehingga tingkat kematian cukup tinggi. Tingkat kematian yang cukup tinggi 
ada hubungannya dengan aktifitas enzim pencernaan dan jenis pakan yang diberikan (Aslianti dan Afifah, 2012). Peningkatan aktivitas enzim pencernaan akan sejalan dengan pertumbuhan larva. Aktivitas enzim pada sistem pencernaan larva stadia awal yang umumnya masih sangat sederhana, diduga sangat terkait dengan kemampuan larva untuk mencerna pakan yang dikonsumsinya (Suryanti, 2002).

Pengetahuan rinci tentang perkembangan ontogenik enzim-enzim pencernaan pada larva ikan merupakan hal yang sangat penting dalam memahami mekanisme pertumbuhan dan kelangsungan hidup pada larva, karena saluran pencernaan larva pada umumnya mengalami perubahan yang sangat cepat, baik morfologi maupun fungsinya selama ontogeni sehingga mempengaruhi kelangsungan hidup larva selama kondisi budidaya. Perkembangan ontogeni enzim pencernaan juga merefleksikan perkembangan saluran pencernaan dan kemampuan pencernaan suatu spesies tersebut sehingga dapat digunakan sebagai indikator pencernaan dan status nutrisi pada awal-awal perkembangan larva (Yulintine et al., 2012)

Serrano dan Traifalgar (2012) menyatakan bahwa pembentukan dan aktivitas enzim pencernaan larva kepiting bakau Scylla serrata berpengaruh terhadap kelangsungan hidup larva. Ong dan Johnston (2006), menyatakan bahwa pengetahuan mengenai perkembangan organ pencernaan dan aktivitas enzim pencernaan sangat penting diketahui untuk setiap spesies krustase dalam hubungannya dengan proses pencernaan pakan. Aktivitas enzim pencernaan yang berkesinambungan memaksimalkan efisiensi pencernaan. Menurut Bakkara et al. (2015) perubahan yang terjadi pada aktivitas enzim pencernaan dipengaruhi oleh perubahan perkembangan saluran pencernaan dan kuantitas atau kualitas komponen pakan. Walaupun perubahan pada aktivitas enzim dan asimilasi pakan berkaitan dengan periode kritis larva, tapi penelitian mengenai aktivitas enzim pencernaan sangat terbatas untuk larva krustase.

Penelitian mengenai aktivitas enzim pencernaan larva berbagai macam organisme perairan telah banyak dilakukan. Perkembangan enzim pencernaan amilase, tripsin, leusin aminopeptidase pada larva kepiting bakau Scylla serrata (Serrano dan Traifalgar, 2012), aktivitas enzim pencernaan larva $S$. serrata, khususnya enzim amilase dan protease (Serrano, 2012). Perez et al. (2010) melakukan penelitian mengenai aktivitas enzim pencernaan khususnya enzim lipase pada udang Penaeus vannamei. Wang (2007) untuk enzim amilase, protease, lipase dan selulosa pada larva Penaeus vannamei, Pavasovic et al. (2004) untuk enzim protease, amilase, selulosa, dan silanase pada larva $S$. serrata. Saborowski et al. (2006) untuk enzim proteinase, tripsin, chymotrypsin, alanin aminopeptidase pada larva Southern king crab Lithodes santolla, Johnston dan Freeman (2005) untuk enzim protease, tripsin, amilase, glukosinase, kitinase, selulosa, dan laminarinase pada beberapa larva kepiting. Pavasovic et al. (2004) untuk enzim lipase, protease, dan selulosa pada larva redclaw crayfish Cherax quadricarinatus. Hasil penelitian yang didapatkan menunjukkan bahwa perkembangan organ pencernaan dan aktivitas enzim pencernaan mempunyai waktu yang berbeda untuk setiap larva organisme.

Tujuan dari penelitian ini adalah untuk mengevaluasi perkembangan ontogenetik dan pola utama aktivitas enzimenzim pencenaan pada larva rajungan $P$. pelagicus sejak awal perkembangan larva dengan menggunakan teknik-teknik biokimia, yang bermanfaat sebagai kontribusi terhadap formulasi suatu protokol nutrisi yang tepat untuk larva rajungan, Hasil penelitian juga diharapkan dapat mendukung peningkatan produksi benih rajungan, sehingga pada usaha budidaya pembesaran hingga ukuran konsumsi dapat berkesinambungan. 


\section{METODE PENELITIAN}

\subsection{Waktu dan Tempat Penelitian}

Penelitian ini dilakukan di BBU Manggar Balikpapan, dimana pada pembuatan pakan dan analisis beberapa peubah dilakukan di Laboratorium Nutrisi dan Manajemen Pakan, Fakultas Perikanan dan Ilmu Kelautan, Universitas Mulawarman, dan Laboratorium Nutrisi dan Teknologi Pakan, Balai Penelitian dan Pengembangan Budidaya Air Payau, Maros.

\subsection{Bahan dan Data}

\subsubsection{Hewan Uji}

Larva yang digunakan berasal dari induk rajungan yang berukuran $173 \pm 8,5$ g/individu dengan lebar dan panjang karapas berturut-turut $12,50 \pm 3,5 \mathrm{~cm}$ dan $6,7 \pm 2,7 \mathrm{~cm}$. Larva tersebut diseleksi dan larva yang berkualitas baik dengan tanda-tanda ukuran larva $>65 \mathrm{~mm}$ dan tertarik pada cahaya dipisahkan.

\subsubsection{Media dan Wadah Pemeliharaan}

Air yang digunakan dalam pemeliharaan larva berupa air laut. Salinitas air media yang digunakan sebesar 29-33 ppt dengan suhu $26-33^{\circ} \mathrm{C}$, dan oksigen terlarut 5 $6 \mathrm{mg} / \mathrm{L}$, dan dilengkapi dengan peralatan aerasi. Sebelum digunakan, media, wadah pemeliharaan dan peralatan yang digunakan terlebih dahulu disterilkan dengan menggunakan khlorin 150 ppm kemudian dinetralisir dengan natrium thiosulfate $\left(\mathrm{Na}_{2} \mathrm{~S}_{2} \mathrm{O}_{3}\right) 25$ ppm dan diaerasi selama 24 jam. Pengukuran oksigen terlarut dan $\mathrm{pH}$ dilakukan dua hari sekali masing-masing dengan menggunakan alat ukur DO meter dan $\mathrm{pH}$ meter sedangkan pengukuran suhu dan salinitas dilakukan setiap hari dengan menggunakan handrefraktometer (ketelitian 0,1 ppt) dan termometer batang (ketelitian $0,1^{\circ} \mathrm{C}$ ).

\subsubsection{Pakan yang Digunakan}

Pakan yang digunakan dalam penelitian ini adalah pakan alami berupa Brachionus sp dan nauplii Artemia, serta pakan buatan komersil yang terdiri dari dua jenis yaitu Japonicus 1 (J1) diberikan untuk larva stadia zoea-3 dan zoea-4 dan Flake untuk stadia megalopa.

\subsubsection{Pemeliharaan Larva}

Larva rajungan yang baru menetas dipelihara pada bak berkapasitas lima ton berjumlah dua buah. Pemberian pakan alami berupa Brachionus diberikan pada larva umur 2-10 hari dengan kepadatan sepuluh individu/mL, kemudian ditingkatkan menjadi 20 individu/mL pada larva umur 11-21 hari, sedangkan Artemia diberikan saat larva umur lima hari sampai akhir penelitian sebanyak 15 individu/mL. Pakan buatan diberikan setelah larva berumur 13 hari dengan metode pemberian pakan secara adlibitum (pengenyangan). Kepadatan Brachionus dan nauplii Artemia dikontrol setiap dua kali sehari yaitu pada pukul 07.00 dan 17.00. Jika jumlah Brachionus dan nauplii Artemia dalam media sudah berkurang maka ditambahkan supaya tetap konstan sepanjang percobaan.

Pengambilan sampel larva dilakukan pada pagi hari sebelum pemberian pakan dilakukan. Pergantian air dalam wadah pemeliharaan larva dimulai saat stadia zoea-2 sebanyak $10 \%$ per hari, kemudian dapat ditingkatkan saat megalopa menjadi $20-50 \%$ per hari.

\subsection{Analisis Data}

Data yang diperoleh disajikan dalam bentuk grafik dan dianalisa secara deskriptif.

\subsection{Pengamatan Parameter}

Pengamatan organ pencernaan secara kimiawi dilakukan dengan cara mengamati aktivitas enzim pencernaan, yaitu meliputi aktivitas enzim amylase, lipase, dan tripsin.

\subsubsection{Uji Aktivitas Enzim Pencernaan}

Pengujian aktivitas enzim $\alpha$-amilase mengikuti metode Bernfield (1955), pengukuran aktivitas lipase mengikuti metode Tietsz dan Friedreck dalam Borlongan 
(1990), sedangkan pengukuran aktivitas tripsin mengikuti metode Walter (Walter, 1984).

\subsubsection{Perubahan Relatif Aktivitas Enzim}

Perubahan relatif pada masingmasing enzim dapat dihitung dengan menggunakan persamaan sebagai berikut:

$\operatorname{PR}(\%)=\left[\mathrm{A}_{\mathrm{t}}-\left(\mathrm{A}_{\mathrm{t}-1}\right)\right] / \mathrm{A}_{\mathrm{t}-1} \times 100 \%$

Keterangan: $\mathrm{PR}=$ Perubahan relatif, $\mathrm{A}=$ Aktivitas enzim pada saat $\mathrm{t}$, At- $1=$ Aktivitas enzim pada saat $\mathrm{t}-1$ (aktivitas enzim sebelum t).

\section{HASIL DAN PEMBAHASAN}

Aktivitas enzim dan perubahan relatif enzim amilase, lipase, dan tripsin larva rajungan hari pertama sampai hari ke dua puluh satu disajikan pada Gambar 1. Gambar
1 dapat diketahui bahwa aktifitas enzim pencernaan sudah terdeteksi sejak larva rajungan berumur satu hari. Terdeteksinya aktifitas enzim pada larva umur tersebut menunjukkan telah berlangsungnya proses hidrolisis pakan, dalam hal ini adalah pakan endogen yang berupa kuning telur dan butiran minyak. Kuning telur banyak mengandung protein sedangkan butir minyak banyak mengandung lemak.

\subsection{Aktivitas Enzim Amilase}

Pada awal kehidupan larva, aktivitas enzim amilase tampak rendah. Hal ini disebabkan walaupun pada umur tersebut organ penghasil enzim sudah terbentuk namun pada organ tersebut masih sangat sederhana, dan larva juga belum mengkonsumsi pakan dari luar.
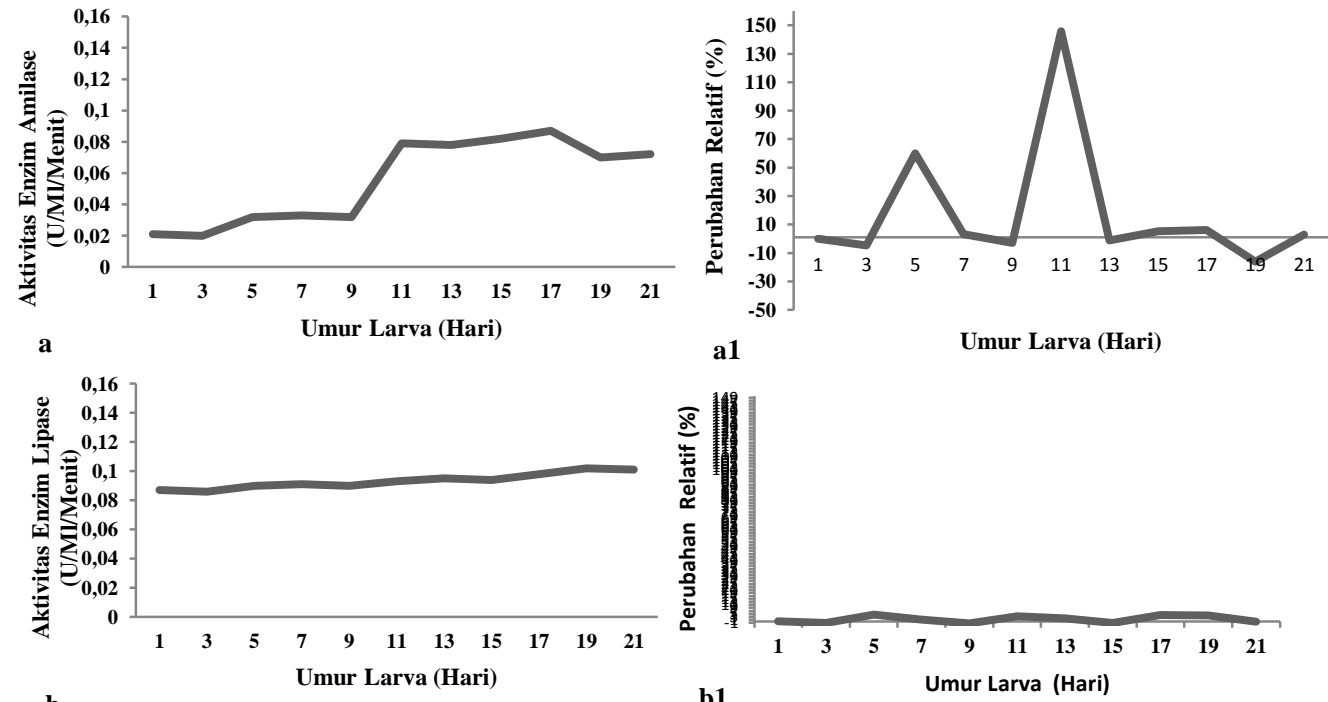$$
\text { b }
$$
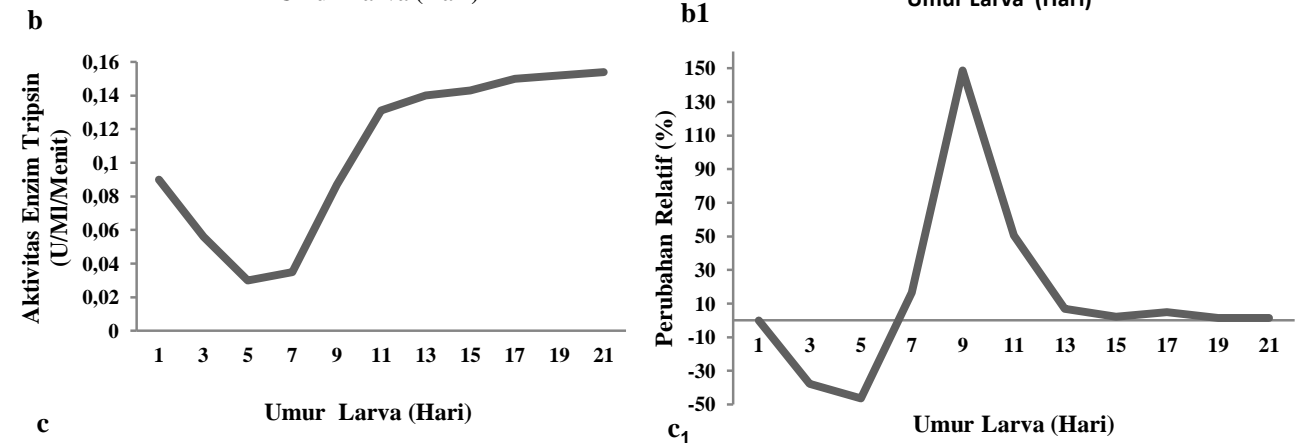

Gambar 1. Aktivitas enzim amilase (a), lipase (b), tripsin (c), dan Perubahan relatif aktivitas enzim amilase $\left(a_{1}\right)$, lipase $\left(b_{1}\right)$, tripsin $\left(c_{1}\right)$ larva rajungan. 
Aktivitas enzim amilase pada larva rajungan hari pertama sebesar $0,021 \mu / \mathrm{mL} /$ menit dan memperlihatkan peningkatan sampai hari kesebelas setelah menetas, dan cenderung mengalami peningkatan sampai hari ketujuh belas dan kemudian menurun secara bertahap sampai akhir penelitian. Aktivitas amilase yang tinggi diikuti dengan penurunan juga telah dilaporkan untuk spesies lainnya (Serrano dan Traifalgar, 2012), Serrano (2012). Aktifitas enzim amilase meningkat pada hari kesebelas $(0,079 \mu / \mathrm{mL} /$ menit $)$ dengan perubahan aktifitas enzim pencernaan sebesar $146 \%$ dan cenderung stabil sampai hari keduapuluhsatu, diduga karena pada hari kesebelas, organ pencernaan larva sudah berada pada fase definitif sehingga sudah mampu menghasilkan enzim pencernaan yang sangat penting untuk mencerna pakan yang diberikan, hal ini didukung oleh Nikhlani (2013) yang menyatakan bahwa lambung, usus, dan hepatopankreas larva rajungan hari kesembilan dan kesebelas sudah dapat dibedakan dengan jelas, bagian luar lambung dikelilingi oleh hepatopankreas, usus juga mengalami perkembangan dengan semakin jelasnya vili yang memenuhi seluruh permukaan bagian dalam usus pada hari kesebelas.

Meningkatnya aktifitas enzim amilase pada hari kesebelas juga diduga disebabkan adanya pengaruh dari pakan eksogen yang diberikan berupa Brachionus, juvenil Artemia dan pakan buatan yang dapat memicu peningkatan aktifitas enzim pencernaan. Hal ini didukung oleh Affandi et al. (2009), yang menyatakan bahwa tinggi rendahnya aktivitas enzim sangat ditentukan oleh organ pencernaan dan ketersediaan substrat. Aslianti dan Afifah (2012) juga menyatakan bahwa substrat makanan yang dikonsumsi oleh larva memberikan kontribusi sebagai enzim eksogeneus yang memicu perkembangan organ pencernaan larva. Nikhlani (2013) juga menyatakan bahwa aktivitas enzim-enzim tersebut sangat berkaitan dengan perkembangan organ pencernaan yang sudah mulai sempurna.
Bertambahnya umur larva, maka organ pencernaan akan berkembang sehingga mempengaruhi produksi enzim pencernaan karena enzim tersebut diproduksi oleh kelenjar pankreas, lambung dan dinding usus (Suryanti, 2002; Melianawati dan Pratiwi, 2011). Jantrarotai et al. (2005) menyatakan bahwa hepatopankreas, lambung, dan usus pada larva rajungan berkembang mulai dari tahap awal zoea sampai tahap-tahap selanjutnya.

Setelah hari ketujuhbelas, aktivitas enzim amilase cenderung mengalami penurunan sampai akhir penelitian, hal ini menunjukkan adanya perubahan kebiasaan makan pada larva rajungan. Pernyataan ini didukung oleh Serrano dan Traifalgar (2012), menyatakan bahwa penurunan oleh aktivitas enzim pada stadia tertentu terjadi untuk mendukung perubahan kebiasaan makan larva. Menurunnya aktivitas enzim amilase pada setelah hari ketujuhbelas sampai akhir penelitian menandakan bahwa pada tahap tersebut larva sudah bersifat karnivora. Hal tersebut didukung oleh Bakkara et al. (2015) yang menyatakan bahwa larva rajungan bersifat karnivora sehingga aktivitas enzim protease cenderung lebih tinggi pada akhir masa larva. Walaupun pada awal kehidupan larva rajungan memiliki kemampuan untuk memanfaatkan karbohidrat, namun tidak adanya karbohidrat dalam makanan maka akan menyebabkan penurunan sekresi amilse (Yulintine et al., 2012).

\subsection{Aktifitas Enzim Lipase}

Berbeda dengan aktivitas amilase yang rendah pada tahap awal kehidupan larva, aktivitas lipase pada umur tersebut cukup tinggi dan cenderung stabil sampai akhir penelitian $(0,087 \mu / \mathrm{mL} / \mathrm{menit}-0,101$ $\mu / \mathrm{mL} /$ menit) dengan perubahan aktifitas enzim pencernaan yang juga cenderung stabil $(0 \%-4,6 \%)$. Aktivitas enzim lipase ditemukan tinggi pada hari pertama setelah penetasan, dan sejak hari pertama sampai hari keduapuluhsatu aktivitas enzim lipase cenderung terus menerus mengalami peningkatan. Hal ini diduga karena tingginya 
kandungan lemak atau lipid pada kuning telur, demikian halnya dengan lemak atau lipid yang terkandung dalam pakan awal (Brachionus dan Artemia) yang mempunyai peran penting dalam proses metabolisme sehingga mendukung organ pencernaan untuk berkembang dan menghasilkan enzim pencernaan. Hal ini sesuai pendapat Melianawati dan Pratiwi (2011); Aslianti dan Afifah (2012) yang menyatakan bahwa nutrisi yang terkandung dalam kuning telur dan pakan alami dapat memacu perkembangan organ tubuh sesuai dengan bertambahnya umur larva dan mempengaruhi produksi enzim. Menurut Serrano (2012), kemampuan larva krustase menghasilkan enzim berkaitan erat dengan perkembangan organ pencernaan, pengertian tentang morfologi pembentukan dan perubahan fisiologi organ pencernaan termasuk kelenjar pencernaan adalah hal yang sangat penting untuk diketahui. Kepiting bakau Scylla serrata, perubahan morfologi larva stadia zoea-3 ke zoea-4 ditandai dengan peningkatan jumlah segmen abdomen dari lima menjadi enam yang berarti gastric mill dari sistem pencernaan mulai berkembang, dan hepatopankreas sudah mulai berfungsi.

Menurut Affandi et al. (2009), sejak awal fase larva, pemanfaatan lemak sebagai sumber energi telah berlangsung, terutama ketika larva belum mengambil pakan dari luar. Perez et al. (2010) menyatakan bahwa aktivitas lipase yang tinggi pada awal stadia larva juga terdeteksi pada udang putih Penaeus vannamei.

\subsection{Aktivitas Enzim Tripsin}

Seperti larva krustase lainnya, aktivitas enzim tripsin sudah terdeteksi pada larva rajungan hari pertama. Aktivitas enzim tripsin yang tinggi pada saat larva baru menetas, karena enzim penetasan dari kelenjar penetasan umumnya tipe tripsin (Serrano, 2012). Pengamatan aktivitas enzim pencernaan tripsin larva rajungan pada hari pertama diperoleh sebesar $0,09 \mu / \mathrm{mL} /$ menit, dan cenderung menurun sampai hari kelima hingga mencapai $0,03 \mathrm{u} / \mathrm{mL} /$ menit dengan perubahan relatif enzim sebesar $-46,42 \%$. Terjadinya penurunan aktifitas enzim tripsin diduga disebabkan pada hari ketiga dan kelima, pakan alami berupa Brachionus dan Artemia sudah diberikan kepada larva, sehingga menyebabkan turunnya aktifitas enzim tersebut, sesuai pendapat Melianawati dan Pratiwi (2011) yang menyatakan bahwa pakan eksogen yang diberikan pada larva memiliki struktur yang berbeda dengan yang ada pada tubuh larva sehingga proses hidrolisis berjalan lambat dan mengakibatkan aktifitas enzim yang terdeteksi rendah. Pada kepiting bakau Scylla serrata, aktivitas enzim tripsin menurun saat pemberian makanan pertama dan cenderung menurun pada tahap berikutnya (Serrano dan Traifalgar, 2012).

Hari ketujuh aktivitas enzim tripsin meningkat lagi menjadi $0,035 \mathrm{u} / \mathrm{ml} /$ menit dengan perubahan relatif enzim sebesar $16,66 \%$ hingga mencapai peningkatan yang tinggi pada hari kesembilan dengan aktivitas enzim sebesar $0,087 \mathrm{u} / \mathrm{mL} / \mathrm{menit}$, dan dengan perubahan relatif $148,57 \%$. Perubahan relatif aktivitas enzim tripsin terus menerus mengalami peningkatan hingga mencapai aktivitas enzim sebesar $0,154 \mathrm{u} / \mathrm{ml} /$ menit dengan perubahan relatif $1,31 \%$ pada hari keduapuluhsatu. Kecenderungan peningkatan aktivitas enzim dapat disebabkan karena peningkatan umur larva dan organ pencernaan sudah berada pada fase definitif. Hal ini didukung oleh Melianawati dan Pratiwi (2012) yang menyatakan bahwa beberapa faktor yang menyebabkan semakin meningkatnya aktifitas enzim pencernaan pada organisme adalah semakin besarnya ukuran tubuh larva diikuti dengan semakin meningkatnya jumlah jaringan penyusun tubuh, termasuk didalamnya adalah jaringan penghasil enzim. Selain itu dapat juga disebabkan semakin besar umur larva akan semakin banyak mengkonsumsi pakan eksogen yang merupakan substrat bagi enzim sehingga akan menstimulir peningkatan aktifitas enzim. Serrano (2012) juga menyatakan bahwa peningkatan aktivitas tripsin sampai 
stadia crablet mengasumsikan perkembangan hepatopankreas yang semakin sempurna.

Tingginya aktivitas enzim tripsin pada larva rajungan hari kesebelas mempertegas bahwa larva tersebut mempunyai kemampuan yang tinggi untuk memanfaatkan protein pada stadia larva. Hal ini berhubungan dengan kebiasaan makan selama siklus hidup rajungan. Menurut Bakkara et al. (2015), rajungan bersifat karnivora pada stadia larva, perkembangan enzim pencernaan menunjukkan pentingnya protein tinggi selama periode pemberian makan pada larva rajungan.

Kemampuan larva krustase menghasilkan enzim pencernaan berhubungan dengan perkembangan organ pencernaan, genetik, dan pakan yang diberikan (Serrano dan Traifalgar, 2012). Level aktivitas enzim yang tinggi ditemukan pada larva penaeid sesaat setelah menetas (Zhou et al., 2009) dan pada larva kepiting bakau Scylla serrata terutama aktivitas amylase dan tripsin (Serrano dan Traifalgar, 2012) selulosa dan protease ditemukan bervariasi pada setiap tahap perkembangan (Pavasovic et al., 2004).

Serrano dan Traifalgar (2012) juga mengatakan bahwa efek interaksi antara tahap perkembangan larva kepiting bakau dan tipe pakan sangat berpengaruh terhadap aktivitas enzim. Pemberian pakan alami pada larva kepiting bakau menghasilkan aktivitas enzim yang tinggi, sehingga pemberian pakan alami pada stadia awal larva sangat penting sebagai sumber enzim eksogeneus. Pada umumnya, aktivitas enzim-enzim tersebut terus meningkat dengan semakin meningkatnya umur larva. Menurut Serrano (2012), peningkatan aktivitas enzim tersebut disebabkan oleh dua faktor yaitu (1) semakin sempurnanya organ penghasil enzim dan (2) meningkatnya konsumsi pakan alami yang merupakan sumber energi eksogen sejalan dengan menyusutnya kuning telur telah menyebabkan peningkatan konsumsi pakan. Menurut Perez (2010), pakan alami yang dikonsumsi memberikan kontribusi terhadap peningkatan aktivitas enzim tersebut dalam saluran pencernaan.
Menurut Serrano (2012), pada stadia telur dan awal larva, dengan organ sekresi belum berkembang enzim yang berperan adalah enzim protein, karbohidrat dan lipid pada oosit yang masak ditemukan di dalam telur dan kantong kuning telur dari larva yang baru menetas. Kuning telur merupakan satusatunya sumber energi bagi perkembangan embrio. Karena pada umur tersebut organ masih dalam perkembangan, setelah fase tersebut maka dibutuhkan enzim dari luar yang berasal dari pakan alami. Dikatakan juga bahwa pada umur satu sampai tiga hari, cadangan lemak yang terdapat pada kantong kuning telur (yolk sac) dihidrolisis dengan bantuan enzim lipase untuk menghasilkan energi bebas. Stadia embrionik dimulai dari akhir fertilisasi sampai mulai mengambil pakan dari luar.

Serrano (2012) menyatakan bahwa pakan alami (Rotifera) yang dikonsumsi oleh larva kepiting bakau memberikan kontribusi yang besar terhadap peningkatan aktifitas protease pada larva zoea-1 sebesar $84 \%$ dan aktifitas amilase mencapai $28,8 \%$. Peningkatan aktifitas enzim pencernaan larva rajungan pada tahap ini juga disebabkan karena enzim endogen sudah mulai disekresikan. Hal ini sesuai hasil pengamatan histologi dimana pada saat larva kepiting bakau berumur tigabelas hari, hepatopankreas, salah satu organ yang mensekresikan enzim-enzim tersebut sudah berada pada tahap definitif (Jantrarorai et al., 2005).

Peningkatan aktivitas enzim yang cukup tinggi dapat dijadikan dasar untuk menentukan saat pakan buatan mulai dapat digunakan. Hal ini sesuai pendapat Affandi et al. (2009) menyatakan bahwa aktivitas enzim pencernaan adalah suatu indikator yang baik untuk menentukan kapasitas pencernaan, ketika aktivitas tinggi dapat diindikasikan secara fisiologis larva siap untuk memproses pakan dari luar.

\subsection{Kualitas Air}

Berdasarkan hasil penelitian, kisaran suhu, salinitas, $\mathrm{pH}$ dan oksigen terlarut (DO) 
media pemeliharaan adalah sebesar $26-33^{\circ} \mathrm{C}$; 29-33 g/L, 8,16-8,24; 5,9-6,8 ppm. Kualitas air ini diasumsikan masih dalam kisaran yang layak untuk pemeliharaan larva rajungan, karena masih dalam batas-batas toleransi yang mendukung pertumbuhan dan klangsungan hidup larva rajungan. Menurut acuan kualitas air untuk media pemeliharaan larva rajungan Portunus pelagicus dalam hal ini kualitas air pemeliharaan, terlihat masih terjaga dan cukup mendukung kehidupan larva hingga akhir penelitian.

Ikhwanuddin et al. (2014) menyatakan bahwa suhu merupakan parameter lingkungan yang mempengaruhi kelangsungan hidup dan perkembangan larva organisme akuatik dan sangat berperan dalam mempercepat metabolisme suatu organisme. Gunarto dan Widodo (2012) menyatakan bahwa suhu air berpengaruh pada waktu yang diperlukan untuk perkembangan larva kepiting bakau. Azra dan Ikhwanuddin (2015) mengkultur larva rajungan pada suhu $25-30^{\circ} \mathrm{C}$ pada salinitas $30-35 \mathrm{~g} / \mathrm{L}$ untuk mengoptimalkan pertumbuhan, kelangsungan hidup dan perkembangan larva rajungan. Ravi and Manisseri (2012) menyatakan bahwa kelangsungan hidup larva rajungan yang dipelihara pada suhu $30^{\circ} \mathrm{C}$ dapat mencapai $14,12 \%$. Pada penelitian Trijuno et al. (2015), kisaran suhu dan salinitas media pemeliharaan adalah sekitar $28^{\circ} \mathrm{C}$ dan 32 g/L. Fujaya et al. (2014) menyatakan bahwa krustase adalah jenis hewan poikilotermik, artinya suhu tubuhnya dipengaruhi oleh suhu lingkungan disekitarnya.

Nilai $\mathrm{pH}$ air selama penelitian berkisar antara 8,16-8,24. Kisaran ini masih optimal untuk pertumbuhan dan tingkat kelangsungan hidup larva rajungan. Menurut Syahidah (2003), pH 7,0-8,5 masih dalam batas normal untuk kehidupan larva rajungan stadia megalopa. Menurut Juwana dan Romimohtarto (2000), pH yang baik untuk megalopa rajungan adalah 7,5-8,5. Juwana (2002) menyatakan bahwa pada pemeliharaan larva rajungan menggunakan $\mathrm{pH}$ berkisar $8-8,5$. Peneliti lain berpendapat bahwa $\mathrm{pH}$ yang optimal untuk pemeliharaan larva rajungan adalah 8,18-9,29 (Oniam et al., 2012), 7,5-8,0 (Soundarapandian dan Tamizhazhagan, 2009).

Oksigen terlarut merupakan suatu parameter pembatas utama karena pengaruh oksigen terlarut sangat penting pada kelangsungan hidup dan pertumbuhan. Oksigen terlarut sangat diperlukan oleh larva rajungan dalam proses respirasi dan proses metabolisme. Pada penelitian ini, kandungan oksigen yang terukur berkisar antara 5,9-6,8 mg/L. Kisaran kualitas air ini dikategori-kan masih layak bagi kehidupan larva rajungan. Menurut Gunarto dan Widodo (2012), kandungan oksigen terlarut 4 ppm merupakan standar yang tidak boleh kurang untuk kelayakan kehidupan organisme dalam perairan. Kelarutan oksigen dipengaruhi oleh beberapa faktor diantaranya suhu, salinitas, $\mathrm{pH}$ dan bahan organik. Jika salinitas tinggi, kelarutan oksigen semakin rendah. Oksigen terlarut di dalam air antara 4-6 ppm dianggap paling ideal untuk tumbuh dan berkembang larva.

\section{KESIMPULAN}

Hasil penelitian uji kimia enzim pencernaan larva rajungan dapat ditarik suatu kesimpulan bahwa aktivitas enzim amilase, lipase dan tripsin mulai terdeteksi pada larva umur satu hari.

Pola aktifitas enzim amilase menunjukkan peningkatan mulai sejak larva berumur satu hari hingga hingga hari ketujuhbelas kemudian cenderung menurun sampai akhir penelitian.

Aktifitas enzim tripsin tinggi pada hari pertama, tapi cenderung menurun pada hari ketiga dan kelima, dan meningkat lagi pada hari ketujuh sampai hari terakhir penelitian. Aktifitas amilase dan tripsin tertinggi selama periode waktu tersebut terjadi pada larva umur sebelas hari.

Aktifitas enzim lipase cenderung stabil dari awal sampai akhir penelitian. Dalam aplikasi budidaya, pemberian pakan 
buatan dengan kandungan karbohidrat, protein dan lemak tinggi sebaiknya dilakukan saat larva berumur sebelas hari.

\section{DAFTAR PUSTAKA}

Affandi, R., D.S. Sjafei, M.F. Rahardjo, dan Sulistiono. 2009. Fisiologi ikan, pencernaan dan penyerapan makanan. Institut Pertanian Bogor. 240hlm.

Aslianti, T. dan Afifah. 2012. Studi aktifitas enzim pencernaan larva ikan kuwe Gnathanodon speciosus yang dipelihara dengan jenis pakan awal berbeda. J. Riset Akuakultur, 7(1):4959.

Azra, M.N. dan M. Ikhwanuddin. 2015. Larval culture and rearing techniques of commercially important crab Portunus pelagicus (Linnaeus, 1758): Present status and future prospects. Songklanakarin J. Science Technology, 37: 135-145.

Bakkara, O.R., S. Aslamyah, dan Y. Fujaya. 2015. Respon perkembangan larva rajungan Portunus pelagicus pada percepatan pergantian pakan alami ke pakan buatan predigest. J. Science and Teknologi, 15(1):74-83.

Bernfield, P. 1955. Method in enzymology. S.P. Academic Press. Colowick, Kaplan, N.O. New York, USA. 150p.

Borlongan, I.G. 1990. Studies on digestive lipases milkfish Chanos chanos. Aquaculture, 89:315-325.

Effendi, I., D. Agustine, dan Widanarni. 2006. Perkembangan enzim pencernaan larva ikan patin Pangasius hypophthalmus. J. Akuakultur Indonesia, 5(1):41-49.

Fujaya, Y., D.D. Trijuno, A. Nikhlani, I. Cahyono, dan Hasnidar. 2014. The use of mulberry Morus alba exstract in the mass production of blue swimming crab Portunus pelagicus L. larvae to overcome the mortality rate due to molting syndrome. Aquatic Science and Technology, 2:1-14.
Gunarto dan A.F. Widodo. 2012. Pengaruh perbedaan suhu air pada perkembangan larva kepiting bakau Scylla olivacea. Prosiding Indo Aqua-Forum Inovasi Teknologi Akuakultur. Indonesia. Hlm.:281-288.

Ikhwanuddin, M., A.N. Liyana, M.N. Azra, Z. Bachok, and A.B. Abol-Munafi. 2014. Natural diet of Blue Swimming Crab Portunus pelagicus at Strait of Tebran, Johor Malaysia. Sains Malaysiana, 43(1):37 - 44

Jantrarotai, P., N. Srakew, and A. Sawanyatiputi. 2005. Histological study on the development of digestive system in zoeal stage of mud crab (Scylla serrata). Kasetsart J. National Sciences, 39:666-671.

Johnston, P.T. and C. Freeman. 2005. The digestive physiology of herbivorous, omnivorous, and carnivorous crustacean larvae. A review. Aquaculture, 155:285-295.

Juwana, S. dan K. Romimohtarto. 2000. Rajungan perikanan, cara budidaya dan menu Masakan. Djambatan. Jakarta. 25hlm.

Juwana, S. 2002. Produksi massal benih rajungan Portunus pelagicus IV. Sistem Budidaya. Dalam: Goenarso et al. (eds.). Prosiding Seminar Nasional Biologi XVI. Hlm.:23 - 28.

Melianawati, R. dan R. Pratiwi. 2011. Pola aktifitas enzim pencernaan larva ikan kerapu macan Ephinephelus fuscoguttatus Forsskal. J. Riset Akuakultur, 6(1):51-61.

Nikhlani, A. 2013. Penentuan time schedule pemberian pakan buatan berfitoekdisteroid untuk menanggulangi sindrom molting pada metamorphosis larva rajungan Portunus pelagicus. Disertasi. Universitas Hasanuddin. Makassar. 202hlm.

Ong, B.L. and D. Johnston. 2006. Influence of feeding on hepatopancreas structure and digestive enzyme activity in 
Penaeus monodon. J. Shellfish Research, 25(11):113-121.

Oniam, V., L. Chuchit, and W. Arkronrat. 2012. Reproductive performance and larval quality of blue swimming crab (Portunus pelagicus) broodstock, fed with different feeds. J. Sci. Technol., 34(4):381-386.

Pavasovic, M., N.A. Richardson, A.J. Anderson, D. Mann, and P.B. Mather. 2004. Effect of $\mathrm{pH}$, temperatur, and diet on Scylla serrata. Aquaculture, 242:641-654.

Perez, R.C., M.A. Navarette, and G.C. Fernando. 2010. Digestive lipase activity through development and after fasting and refeeding in the whiteleg shrimp Penaeus vannamei. Aquaculture, 30:163-168.

Ravi, R. and M.K. Manisseri. 2012. Survival rate and development period of the larvae of Portunus pelagicus (Decapoda, Brachyura, ortunidae) in relation to temperature and salinity. Fisheries and Aquaculture J., 12:1-8.

Saborowski, R., S. Thaje, J.A. Calcagno, G.A. Lovrich, and K. Anger. 2006. Digestive enzymes in the ontogenetic stages of the southern king crab Lithodes santolla. Marine Biology, 149:865-873.

Serrano, A.E. 2012. Ontogeny of the endogeneous and exogeneous amylase and total protease activities in mud crab, Scylla serrata larvae fed live food. AACL Bioflux, 2(5):1578-1584.

Serrano, A.E. and R.F. Traifalgar. 2012. Ontogeny and induction of digestive enzymes in Scylla serrata larvae fed live or artificial feeds or their combination. AACL Bioflux, 5(3):101 -111 .
Suryanti, Y. 2002. Perkembangan aktifitas enzim pencernaan pada larva/benih ikan baung Mystus nemurus C.V. J. Penelitian Perikanan Indonesia, 8(3):15-18.

Syahidah, D. and I. Rusdi. 2003. The effect of different initial feeding time of micro diets as artificial feed to survival rate of mud crabs larvae Scylla paramamosain. International Seminar on Marine and Fisheries 1516 December 2003. Jakarta Convention Center. 20-22pp.

Trijuno, D.D., Y. Fujaya, Agrivanti, dan S. Marhama. 2015. Quality of blue swimming crab Portunus pelagicus larvae from domesticated broodstock. Aquaculture Indonesiana, 16:22-28.

Walter, H.E. 1984. Methods of enzymatic analysis. Wein-heim. Verlag Chemie. $277 \mathrm{p}$.

Wang, Y.B. 2007. Effect of probiotics on growth performance and digestive enzyme activity of the shrimp Pennaeus vannamei. Aquaculture, 269:259-264.

Yulintine, E. Harris, D. Jusadi, R. Affandi, dan Alimuddin. 2012. Perkembangan aktifitas enzim pada saluran pencernaan larva ikan betok Anabas testudineus bloch. Bionatura J. Ilmuilmu Hayati dan Fisik, 14(1):59-67.

Zhou, X.X., Y.B. Wang, and W.F. Li. 2009. Effect of probiotic on larvae shrimp Penaeus vannamei based on water quality, survival rate and digestive enzyme activities. Aquaculture, 287: 349-353.
Diterima
6 Agustus 2016
Direview
24 Oktober 2016
Disetujui : 2 November 2017 